\title{
Interplay of Shared Leadership Practices of Principals, Teachers' Soft Skills and Learners' Competitiveness in COVID 19 Era: Implications to Economics of Educational Leadership
}

\author{
KANITTHA CHARERNNIT ${ }^{1}$, ANSHU MATHUR ${ }^{2}$, KANNAPAT KANKAEW ${ }^{3}$, \\ JOEL ALANYA-BELTRAN ${ }^{4}$, P. JUSTIN SUDHAKAR ${ }^{5}$, SHRADHANVITA SINGH ${ }^{6}$, GILBERT C. \\ MAGULOD, JR. ${ }^{7}$, JOSEPH JEAN SINCHITULLO GÓMEZ ${ }^{8}$, NGANGBAM DEVKANTA SINGH ${ }^{9}$ \\ ${ }^{1}$ SUAN SUNANDHA RAJABHAT UNIVERSITY, THAILAND, E-mail: kanittha.ch@ssru.ac.th \\ ${ }^{2}$ AMITY UNIVERSITY NOIDA, INDIA, E-mail: amathur@amuty.edu \\ ${ }^{3}$ SUAN SUNANDHA RAJABHAT UNIVERSITY, THAILAND \\ ${ }^{4}$ UNIVERSIDAD TECNOLÓGICA DEL PERÚ, PERÚ, E-mail: c18121@utp.edu.pe \\ 5JIGJIGA UNIVERSITY, INDIA \\ ${ }^{6}$ AMITY UNIVERSITY HARYANA \\ ${ }^{7}$ CAGAYAN STATE UNIVERSITY, PHILIPPINES \\ ${ }^{8}$ UNIVERSIDAD NACIONAL DE INGENIERÍA, PERU, E-mail: jsinchitullog@uni.edu.pe \\ ${ }^{9}$ MANIPUR UNIVERSITY, INDIA, E-mail: ngangbamdev@gmail.com
}

\begin{abstract}
The COVID 19 pandemic had a significant impact on both the administration and instructional delivery. A close partnership between administrators and teachers is essential to students' overall growth, particularly in this COVID 19 era. This study employed a descriptive correlational research design. A survey was done using online to selected schools in South East Asian countries. From the study, it can be inferred that the highly positive results are seen on the level of principal shared leadership practices are manifested by the school heads, teachers' soft skills enhancement, and learners' competitiveness. The school heads are capable of exuding shared leadership aspects on effective communication, proper coordination, direction, and influence. Test of relationship showed a positive interplay between principals' shared leadership with the selected variables on teachers' soft skills and learners' competitiveness. Research on the comparative impacts of leadership styles will assist policymakers and practitioners in better understand which leadership techniques are most successful for specific elements of school reform efforts, in our view. Further, the implications of this study will help teachers better their interpersonal and administrative abilities while administrators are urged to continue to improve their leadership techniques. The result of this present study will provide a way for policymakers and other stakeholders to fund allocation and develop a plan of action to strengthen principal leadership in the COVID 19 era.
\end{abstract}

Keywords: Shared leadership; Soft skills; Learners' performance; COVID 19; Learning.

JEL Classification: M00, M10, M19

Received: June 24, 2021

Accepted: September 10, 2021 


\title{
Interacción de las Prácticas de Liderazgo Compartido de los Directores, las Habilidades Blandas de los Profesores y la Competitividad de los Alumnos en la Era COVID 19: Implicaciones para la Economía del Liderazgo Educativo
}

\author{
KANITTHA CHARERNNIT ${ }^{1}$, ANSHU MATHUR ${ }^{2}$, KANNAPAT KANKAEW ${ }^{3}$, \\ JOEL ALANYA-BELTRAN ${ }^{4}$, P. JUSTIN SUDHAKAR ${ }^{5}$, SHRADHANVITA SINGH ${ }^{6}$, GILBERT C. \\ MAGULOD, JR. ${ }^{7}$, JOSEPH JEAN SINCHITULLO GÓMEZ ${ }^{8}$, NGANGBAM DEVKANTA SINGH ${ }^{9}$ \\ ${ }^{1}$ SUAN SUNANDHA RAJABHAT UNIVERSITY, THAILAND, E-mail: kanittha.ch@ssru.ac.th \\ ${ }^{2}$ AMITY UNIVERSITY NOIDA, INDIA, E-mail: amathur@amuty.edu \\ ${ }^{3}$ SUAN SUNANDHA RAJABHAT UNIVERSITY, THAILAND \\ 4UNIVERSIDAD TECNOLÓGICA DEL PERÚ, PERÚ, E-mail: c18121@utp.edu.pe \\ ${ }^{5}$ JIGJIGA UNIVERSITY, INDIA \\ ${ }^{6}$ AMITY UNIVERSITY HARYANA \\ ${ }^{7}$ CAGAYAN STATE UNIVERSITY, PHILIPPINES \\ 8UNIVERSIDAD NACIONAL DE INGENIERÍA, PERU, E-mail: jsinchitullog@uni.edu.pe \\ ${ }^{9}$ MANIPUR UNIVERSITY, INDIA, E-mail: ngangbamdev@gmail.com
}

\begin{abstract}
RESUMEN
La pandemia de COVID 19 tuvo un impacto significativo tanto en la administración como en la enseñanza. Una estrecha colaboración entre los administradores y los profesores es esencial para el crecimiento general de los estudiantes, especialmente en esta era de COVID 19. Este estudio empleó un diseño de investigación descriptivo correlacional. Se realizó una encuesta a través de Internet en escuelas seleccionadas de países del sudeste asiático. Del estudio se desprende que los resultados son muy positivos en cuanto a las prácticas de liderazgo compartido de los directores, la mejora de las habilidades sociales de los profesores y la competitividad de los alumnos. Los directores de los centros educativos son capaces de exudar aspectos de liderazgo compartido en cuanto a la comunicación efectiva, la coordinación adecuada, la dirección y la influencia. Las pruebas de relación mostraron una interacción positiva entre el liderazgo compartido de los directores y las variables seleccionadas sobre las habilidades sociales de los profesores y la competitividad de los alumnos. La investigación sobre los impactos comparativos de los estilos de liderazgo ayudará a los responsables políticos y a los profesionales a comprender mejor qué técnicas de liderazgo son más exitosas para elementos específicos de los esfuerzos de reforma escolar, en nuestra opinión. Además, las implicaciones de este estudio ayudarán a los profesores a mejorar sus habilidades interpersonales y administrativas, al tiempo que se insta a los administradores a seguir mejorando sus técnicas de liderazgo. El resultado del presente estudio proporcionará una vía para que los responsables políticos y otras partes interesadas financien la asignación y desarrollen un plan de acción para fortalecer el liderazgo de los directores en la era COVID 19.
\end{abstract}

Palabras clave: Liderazgo compartido; Habilidades blandas; Rendimiento de los alumnos; COVID 19; Aprendizaje. Clasificación JEL: M00, M10, M19

Recibido: 24 de Junio de 2021

Aceptado: 10 de Septiembre de 2021 


\section{Introduction}

Academic leaders made a choice to adopt a "digital campus" approach after considering the increased unpredictability and severity of the next coronavirus pandemic (Harris, 2020). Deciding to turn to remote teaching and learning necessitated transformational learning for all stakeholders, and working through the many administrative and organizational obstacles have been tiring and frustrating (Al Saidi et al., 2020, Vu et al., 2020). Many different stakeholders will probably have a hard time adapting to delivering online courses, which may demand a variety of adjustments, including methods of thinking, handling values, and even how to run a company. When faced with social distancing techniques, leadership practitioners chose to start doing their classes remotely, despite some professors being unhappy with the fact that they weren't informed on the issue (Ziauddeen et al., 2020). To acquaint faculty with contemporary remote digital teaching and learning technologies, academic leaders throughout the country hurriedly planned events. Faculty who are hesitant about technology-enhanced education will be motivated by genuine leaders. Some academics have no idea what they're doing and are worried about their well-established teaching and learning routines being disturbed. Crisis management in academics will need appropriate leader behaviours suited to the environment of empathy, compassion, and adaptability (Boin, Lodge, \& Luesink, 2020, Hutagalung, Purwanto, \& Prasetya, 2020, Arcinas et al., 2021, Ignacio et al., 2020, Lopez et al., 2021, Nuncio et al., 2020).

A new toolset of intellectual stimulation, idealized influence, and inspiration is needed for academic leaders to assist the school community in making the switch to online learning (Bacher-Hicks, Goodman, \& Mulhern, 2021, Dong, Cao, \& Li, 2020, Hussein, et al., 2020). Academic administration should moderate faculty expectations, even though some faculty have rapidly created acceptable online course offerings due to their inherent desire to innovate. Online courses that have been thrown up in a hurry aren't always ideal, and some may be poor. Faculty performance will be boosted by academic leaders who can use the abilities and talents of the campus collective by using a distributed situational leadership approach (Chiodini, 2020, Hussein et al., 2020, Swaminathan et al., 2021).

A shared leadership style encourages collaboration and inclusivity. The long-established leadership theory (Gyang,2020, Love et al., 2020, Netolicky, 2020) works well in academia where followers are experienced, knowledgeable, and intrinsically motivated. Faculty may be capable of building better quality online course offerings that establish a community of learners capable of working together to overcome the teaching and learning challenges posed by the current coronavirus crisis when leadership is decentralized. A school head must encourage their teachers to embark on new learning tasks, which helps them feel empowered to improve their abilities. Everyone becomes ecstatic when the boss recovers. It's critical for the success of a team to have leadership play a central role. Shared leadership is a successful means of helping schools remain relevant and competitive in an everchanging environment. Shared leadership increases group spirit and trust and has a positive effect on how members collaborate on their shared beliefs and goals (Gonzales \& Jackson, 2020, Mukaram et al., 2021, Price, 2021).

While leading others, principals set goals and objectives for them to achieve. As a leader, you have an impact on how events are interpreted, how goals and strategies are chosen, how work is organized, how people are motivated to achieve goals, how you maintain cooperative relationships, how members develop their skills and confidence, and how you enlist the support and cooperation of people outside of your organization (Ardley \& Goodloe, 2020, Reyes-Guerra et al., 2021, Sterrett \& Richardson, 2020, Sumarjoa \& Muhammadc, 2021). In education, leadership includes collaboration, where individuals (stakeholders) at various levels work together to achieve a common goal. An effective leader transforms policy into actionable behaviors and attitudes by using creative and imaginative methods. In addition, it encourages students to respond quickly and adapt their studies to unpredictable, high-speed classroom situations. Teacher collaboration with administrators may help teachers discover innovative strategies for achieving the potential of their pupils, supporting student 
participation while offering more resources (Ahlström et al., 2020, Allal-Chérif et al., 2021, Chaaban et al., 2021).

\subsection{Research Context and Gap}

Although we do not yet know how to define the shared leadership of managers as related to company structure, job assignments, and success principles, there are still information gaps in this area. School governance, effective schooling, and improved performance are among the essential modern educational administration issues the South East Asian countries face. Our new research focuses on school administrators and instructors to be more effective at developing educational programs and using current policies to make students more prepared, more skilled, and more competitive. To improve the services provided in the local school system, the board of education should study existing practices and available resources since these details would allow the administration to figure out how to best use available resources.

In this study, the researchers attempted to determine whether principal leadership and teachers' soft skills training were essential to student performance in the classroom. Administrators believed it was necessary to combine the ideas and efforts of instructors to keep them focused on improving teaching quality and driving a commitment to the school's growth goals. This may be accomplished by exploring the school's resources. It will take greater trust and accountability for teachers to feel comfortable collaborating in an atmosphere that promotes learning. Teachers who are prepared with such abilities as problem-solving, critical thinking, and communications can better adapt to the everchanging situation of the country. Learner-centric decentralization gets a boost with this. Principals are also given more flexibility for stakeholders to improve their instructional procedures, which helps them become more empowered and be responsible for their school-site personnel.

Administrators' responsibility is to guarantee that their teachers have the necessary tools to achieve their goals (Díez et al., 2020, Navaridas-Nalda et al., 2020, Shen et al., 2021, Smith et al., 2021, Zhou, 2021). Teachers' professional development should include guidance from their mentors to help them reach their goals, and mentors should construct their lesson plans to follow this guideline. It is vital that they create positive, respectful, and trustworthy connections with their workers to make them feel valued and supported by administrators who are satisfied in their jobs have an easier time getting along with colleagues and collaborating. Teachers who spend time working with school administrators to learn about educational programs and initiatives tend to have more cooperative relationships with them. In turn, if educators continuously strive to improve their own instruction, they may positively influence their students' education.

Since teachers must take on so many duties in school, they help administrators by doing other tasks. It is common for teachers to be alone in the school while they oversee it. Teachers have to handle classroom management and the school. The principals turn over administrative tasks to teachers while they are out of the office. Teacher background has a significant role in the issue. The study aims to discover the administration's level of cohesiveness with teachers and their positive influence on their pupils through strong communication, problem-solving, and a strong support network. Teachers may increase their productivity using deficiencies as opportunities when their principals follow an effective strategy presented by different systematic reviews (Schott, van Roekel, \& Tummers, 2020, Shen et al., 2020 , Smith et al., 2021). Teachers who have confidence in their job have the propensity to help others perform to the same level as them, going above and beyond the expectations of the business and assisting them with reaching their objectives. People are far more likely to do their best if their boss is leading them. Hence, this study was conducted.

\subsection{Objectives of the Study}

Generally, this study aims to assess the interplay between the principals' shared leadership practices, teachers' soft skills development, and pupils' competitiveness. Specifically, it seeks to: (1) assess the level of shared leadership practices of the principals in terms of communication, 
coordination, direction, and influence; (2) ascertain the level of soft skills development of the teachers in terms of problem-solving, work ethics, flexibility, and interpersonal relationship; (3) explore the interplay the principals' shared leadership practices, teachers' soft skills development, and pupils' competitiveness.

\section{Methodology}

\subsection{Research Design}

A descriptive survey correlational research strategy was used in this study's analysis. Surveys with closed-ended questions were utilized to achieve the study's goals. It is essential to examine the relationships between variables in a research project. Thus, correlational research is being utilized (Bloomfield \& Fisher, 2019, Zadeh et al., 2021). Correlational research may be used to assess the degree of a relationship between two variables. The researcher may make an informed prediction based on the connections found throughout the research process. G-Power analysis with a 0.25 effect size was used to identify them. To conduct the study, a researcher created a questionnaire based on reading a variety of sources. Four education professionals endorsed them. As a result, the instrument's dependability was determined by Cronbach's alpha. The authorities issued a letter asking for authorization, signed by them. Mean, and rank was used to characterize the collected data. Correlational analysis was used to evaluate the study's hypotheses. Mean, rank, and correlational analysis were used in the research.

\subsection{Research Participants, Sampling Procedure, and Ethical Considerations}

It was carried out in 38 selected schools with a 'large' population of teachers that merits a principal item for the school head. Respondents were assured that the survey data shall be held highly confidential and shall only be used for the study. From a population of 1,890 , the selected 480 instructors were used to create the survey. A Raosoft Sampling Size Calculator with a margin of error of $5 \%$ and a confidence level of $95 \%$ was used to calculate the number of samples. According to the following criteria, research locations were chosen: : (1) Must have a student population of at least 1,000 , (2) Must be performing school according to Ministry of Education statistics, (3) "Must be a large school" Random stratification was employed in the research. Three were the random start number for instructor replies and five being the random start number for student answers, as shown by the table below. Participation in the study was voluntary for both groups of individuals, who gave their informed permission before participating.

Table 1 Participants Gender-Profile Characteristic

\begin{tabular}{|l|c|c|}
\hline & Teacher-respondents & Percentage Distribution \\
\hline Male & 162 & $\mathbf{3 4 \%}$ \\
\hline Female & 318 & $66 \%$ \\
\hline Total & $\mathbf{4 8 0}$ & $\mathbf{1 0 0 \%}$ \\
\hline
\end{tabular}

Legend: 4.20-5.00: Very High/ Strongly Agree; 3.40-4.19: High/ Agree; 2.60-3.39: Moderate/ Undecided; 1.80- 2.59: Low/ Disagree; 1.79: Very Low/ Strongly Disagree

Table 1 shows that women outnumbered males in the poll. According to this, the majority of teachers are women. Before the research began, each participant was given a copy of the participant information and data protection forms. Additionally, the respondents' names, confidentiality, and privacy were carefully monitored both before and after the data was made available to the public and later. To them, it was essential that they were fully aware of the research's only purpose. Any information collected about them was kept strictly private and was only used for this purpose. As a result of the COVID 19 epidemic, data was collected through google survey, zoom application phone, and messenger video call. Data collection was primarily placed at night to accommodate participants' schedules. The participants were promised that the information they provided would remain private. 


\subsection{Research Instruments}

\subsubsection{Principal Shared Leadership Questionnaire}

Principals' leadership behaviors were assessed using the distributed leadership scale established by Özkan and Çakır (2017) for the school setting. Thirty-two components make up the scale, which is based on existing research on dispersed leadership. On a 5-point Likert-type scale, each question asks teachers to rate how often their principal engages in dispersed leadership activities. There are four aspects to this: formal framework communication, coordination, direction, and influence (CFA \& EFA). As a whole, the scale is well-suited to the educational setting (X2/df is 2.23 and RMSEA and SRM are both 0.063 , NFI is 0.96 , and $\mathrm{CFI}=0.98$ ).

\subsubsection{Teachers' Soft Skills}

The teachers' soft skills were measured using Ngang, Yunus, and Hahim (2015) questionnaire. Some people define soft skills as non-academic talents, such as communication, critical thinking, and problem-solving. Others define soft skills like entrepreneurship, ethics, professional moral skills, and leadership abilities. They include three components of soft skills that will be taught at colleges and universities. The respondents are required to answer each of the items by selecting the response or Likert option that they believe is most relevant regarding what is currently in place at the school regarding staff motivation by the principals. The instrument has computed Cronbach alpha of $(0.87)$.

\subsubsection{Learners' Competitiveness}

To measure leaners' competitiveness. It was based on the questionnaire of Grum and Grum (2015) on the competitiveness, training, and culture of students. Responses were solicited on a 5-point Likert scale ranging from 1 (strongly disagree) to 5 (strongly agree). Frey and Tatum (2016) reported a reliability coefficient of .91 for this scale.

\subsection{Data Analysis}

To do this, the researchers utilized the following data analysis methods: Responses were evaluated using frequency distribution and percentile rankings, while the mean, as well as the weighted average and standard deviation, were utilized to calculate the variables' values. For factors, a formal comparison was made using a T-test and an ANOVA. Scales like these were used: 4.20-5.00: Very High/ Strongly Agree; 3.40-4.19: High/ Agree; 2.60-3.39: Moderate/ Undecided; 1.80- 2.59: Low/ Disagree; 1.79: Very Low/ Strongly Disagree. SPSS 23 was used to analyze the data.

\section{Results and Discussion}

\subsection{Assessment of the principals' Shared Leadership}

There are four main areas of standard leadership practices among principals: communication, coordination, training, and influence, as seen in Table 1. The total communication mean was 4.58, which is considered to be extremely high by most. According to the study's findings, a strong communication system among instructors is essential for administrators to accomplish the institution's aims and objectives. According to studies, principals' shared communication methods empower school constituents to address problems and concerns in a more meaningful and pressure-free manner, allowing them to see the other side of the coin (Elfrianto et al., 2020, Sapianet al, 2020, Smith et al., 2021). In like manner, Yao, You, \& Zhu (2020) also agreed with this result. As part of a working environment that may develop trust among its instructors, school heads' communication abilities must be dynamic and a linking element. 
Table 1 Principals' Motivational Skills and Teachers' Perception of their work

\begin{tabular}{|c|c|c|c|}
\hline $\begin{array}{c}\text { Principals' Shared Leadership } \\
\text { Practices }\end{array}$ & $\begin{array}{c}\text { Mean } \\
(\mathbf{n = 4 8 0 )}\end{array}$ & StD & Description \\
\hline Communication & 4.58 & 0.54 & Very High \\
\hline Coordination & 4.28 & 0.23 & Very High \\
\hline Direction & 4.65 & 0.67 & Very High \\
\hline Influence & 4.46 & 0.23 & Very High \\
\hline
\end{tabular}

Legend: 4.20-5.00: Very High/ Strongly Agree; 3.40-4.19: High/ Agree; 2.60-3.39: Moderate/ Undecided; 1.80- 2.59: Low/ Disagree; 1.79: Very Low/ Strongly Disagree

In this case, the total coordination score was 4.28 , which is considered extremely high. However, this result suggests that administrators have a modest sense of coordination when it comes to educating and motivating their teachers to carry out their duties for school improvement. Researches showed that administrators' influence on teachers impacted the teaching-learning process in school climates by encouraging educational possibilities (Debbarma \& Durai, 2021, Schott, van Roekel, \& Tummers, 2020, Shen et al., 2020). It was concluded that school administrators must follow educational advances to enable teachers to create dynamic classroom environments.

There is a fairly high value of 4.65 in the overall mean for direction. The findings suggest that administrators guide their instructors in school programs and activities in a moderate manner, according to Situational Leadership Theory (Fernandez \& Vecchio, 1997, Goodson et al., 1989, Vecchio, 1987). The principal's leadership style adapts to the development level of teachers and the objectives to be accomplished. This result lends credence to this theory. As a result, principals' shared leadership approaches establish excellent connections with teachers, students, and stakeholders inside the institution for the development of the curriculum and teaching-learning process as well as school policies and the excellent academic performance of its students. The study concluded that school administrators' initiative behaviors impacted instructors' views on work. Due to the introduction of a beneficial circumstance, the connection between the headteachers and their pupils may improve.

Overall, the influence score was 4.46, which is considered to be strong. According to this study, administrators have a modest effect on their teachers because they serve as role models for excellent leadership techniques. Leadership style affects staff performance, resulting in increased productivity (Al-Mekhlafi \& Osman, 2019, Lai et al., 2014, Magulod Jr, 2017, Saleem et al., 2020). Hence, teachers' dedication to delivering excellent teaching, work efficiency, and school equality is indicated by the article's shared influence practice of effective principals.

\subsection{Teachers' Soft Skills Assessment}

Table 2 shows the respondents' views of the degree of soft skill development among instructors in terms of problem-solving, work ethics, adaptability, and interpersonal relationships. As can be seen, the total mean was 4.28, which many consider being extremely high. As a result of this study, instructors seem to be excellent problem solvers. As a result, it seems that instructors can resolve their own internal issues with the help of feasible interventions. Researchers found that problem-solving skills positively impacted innovation behavior (Kar et al., 2010, Qizi, 2019, Yavuz et al., 2010). Problemsolving skills are thus crucial for teachers to collect the knowledge they need to make informed choices. Delegating responsibility for finding alternative answers methodically prevents more harm from occurring in the institution. Further, it entails the creation, execution, and assessment of a plan of action to alleviate the problems at hand.

The total mean for work ethics was 4.25 , which is considered to be extremely high. As a result, the instructors are expected to adhere to a strict code of conduct. This implies that instructors adhere to a set of moral standards that includes ideals towards excellent work. It means that instructors with high ethical standards are more likely to resolve workplace disputes transparent and accountable. It also acts as a moral compass for developing professional competence in their everyday interactions with one another (Sanger \& Osguthorpe, 2011). Finally, a score of 4.34, which is considered to be quite 
good in this case. As a result of this study, teachers seem to be extremely adaptable when it comes to their different duties. As anticipated, teachers can adjust to every circumstance since they work with a variety of students, parents, and coworkers to improve their school's performance. That's because flexibility is the capacity to alter one's behaviors and emotions to react to various emotions effectively, according to studies (Star et al., 2015, Wanner \& Palmer, 2015). Teachers' flexibility skill allows them to retain a sense of balance and adjust to changes in the workplace such as curricular, methodological and instructional changes while maintaining a high level of productivity.

Table 2 Assessment of Teachers' Soft-Skills

\begin{tabular}{|c|c|c|c|}
\hline & $\begin{array}{c}\text { Mean } \\
(\mathbf{n = 4 8 0})\end{array}$ & StD & Description \\
\hline Problem-solving & 4.28 & 0.12 & Very High \\
\hline Work ethics & 4.25 & 0.15 & Very High \\
\hline Flexibility & 4.34 & 0.34 & Very High \\
\hline Interpersonal relationship & 4.26 & 0.56 & Very High \\
\hline
\end{tabular}

Legend: 4.20-5.00: Very High/ Strongly Agree; 3.40-4.19: High/ Agree; 2.60-3.39: Moderate/ Undecided; 1.80- 2.59: Low/ Disagree; 1.79: Very Low/ Strongly Disagree

Overall interpersonal connection scores were 4.46, which is regarded as extremely high. As a result of the study, instructors seem to have a strong working relationship with their coworkers. As a result of this, instructors are better equipped to express their sympathy, support, and respect to their coworkers. The results are in line with studies that interpersonal relationships in education are assessed in terms of affiliation, which defines the degree of emotional immediacy, warmth, and support in the encounter (Rebele \& Pierre, 2019. Bhute et al., 2021). Teacher soft skills enable them to establish a solid connection with their principal, colleagues, and students by exercising excellent interactions and conduct while working more successfully as a team, according to the study's conclusion

\subsection{Assessment of Learners Competitiveness}

On the basis of competition, training, and school culture, respondents' average views of students' competitiveness are given in Table 3. There was a mean of 4.45, which is considered high. Students are somewhat exposed to contests depending on their acquired potentials, according to the study's findings. In other words, students typically improve their talents and skills before contests. The result is an increase in self-confidence, which they use to accomplish their goals. As a result, students' intrinsic motivation pushes them to improve their performance by adopting excellent work habits and displaying responsible and competitive conduct (Erol \& Kurt, 2017, Whitaker \& Valtierra, 2018).

Table 3 Assessment of Learners Competitiveness

\begin{tabular}{|c|c|c|c|}
\hline & $\begin{array}{c}\text { Mean } \\
(\mathbf{n = 4 8 0})\end{array}$ & StD & Description \\
\hline Competitiveness & 4.45 & 0.17 & Very High \\
\hline Training & 2.59 & 0.19 & Moderate \\
\hline School culture & 4.47 & 0.33 & Very High \\
\hline
\end{tabular}

Legend: 4.20-5.00: Very High/ Strongly Agree; 3.40-4.19: High/ Agree; 2.60-3.39: Moderate/ Undecided; 1.80- 2.59: Low/ Disagree; 1.79: Very Low/ Strongly Disagree

On average, there was a high average score of 2.59 , which is considered moderate on training. According to the findings, due to budgetary limitations and inadequate resources, students are only minimally exposed to training. Contests encourage students to work harder and accomplish more in a more competitive atmosphere. As Shimotsu-Dariol, Mansson, \& Myers (2012) noted, participating in competition helps youngsters to overcome their anxieties and insecurities. Students' potential, talents, and abilities are harnessed through adopting new ideas and techniques. Students benefit from a competitive atmosphere when it comes to developing abilities and sportsmanship in their academic and non-academic activities. Their well-being improves as a result of the instruction they receive.

There was an overall mean score of 4.47 in the table. According to the study, the findings suggest that students have a reasonable understanding of their fundamental beliefs, habits, and set of goal- 
oriented activities. Findings from Grosemans et al. (2015) research confirm the importance of teachers' assistance and schools focusing on students' interests and abilities to create the school's culture. Overall, good school culture enables students to participate successfully in the teaching and learning process. As the study concluded, encouraging meaningful parental participation, setting norms and values, recognizing personal accomplishments, and modeling good conduct, also adds to the school's high-quality educational environment.

\subsection{Relationship between Principals Level of Leadership and selected Variables}

Table 4 depicts the relationships between the principal level of shared leadership, teachers' soft skills, and learners' competitiveness. This shows that there is a significant positive interplay of principal shared leadership and the selected variables. Hence, the null hypothesis of the study is rejected. This would imply that principal leadership and empowerment influence all spheres of school operations, human resources, and academic performance. A closer look at the data shows that Principals' Shared Leadership and Teachers' Soft Skills Enhancement are positively correlated with the r-value of .79 and as evidenced with the computed p-value of 0042, which is lower than the alpha level of 0.05 . this means that the higher the principal shared leadership in four domains such as communication, coordination, direction, and influence, the higher the teachers also manifest soft skills enhancement along with problem-solving, work ethics, flexibility, and interpersonal relationship. This finding shows that the ability of the school head to manage the human resource is a factor of quality school leadership amidst COVID 19 pandemic. Hence, school heads to manifest shared solid leadership skills to carry out school plans and operations despite the implementation of remote learning. When school heads will manifest stronger communication and coordination direction and influence the higher the teachers' ability to foster problem-solving skills, work ethics, flexibility, and interpersonal relationships (Lee et al., 2011, Hulpia \& Devos, 2010) Selamat et al., 2013). In like manner, when principals' Shared Leadership and Learners Competitiveness are taken into account, the data reveal that it is likewise positively correlated with the computed r-value of .83 and p-value of .004 lower than the alpha level of 005. This would imply that there is a positive interplay among the two variables. Such a positive relationship means that the higher the school head promotes strong shared leadership practices on communication, coordination direction, and influence, the higher the teachers also manifest soft skills enhancement along competitiveness, training, and school culture. This justifies that when school heads are capable of manifesting good leadership practices, the more likely the schools will have stronger learners' perspectives on competitiveness, training, and school culture (Shen et al., 2020, Scott-Young et al., 2019).

Table 4. Correlations of Principals' Shared and related variables

\begin{tabular}{|c|c|c|c|c|}
\hline Bivariate & Pearson-r & $\begin{array}{c}\text { Interpretation } \\
\text { of } \mathbf{~}^{\mathbf{2}}\end{array}$ & p-value & $\begin{array}{c}\text { Interpretation of } \\
\text { p-value }\end{array}$ \\
\hline $\begin{array}{c}\text { Principals' Shared Leadership } \\
\text { and Teachers' Soft Skills } \\
\text { Enhancement }\end{array}$ & $.79^{*}$ & Correlated & .042 & $\begin{array}{c}\text { *significant at } \\
0.05\end{array}$ \\
\hline $\begin{array}{c}\text { Principals' Shared Leadership } \\
\text { and Learners Competitiveness }\end{array}$ & $.83^{*}$ & Correlated & .004 & $\begin{array}{c}\text { *significant at } \\
0.05\end{array}$ \\
\hline
\end{tabular}

${ }^{*}=$ significant at 0.05 level; $\mathrm{ns}=$ not significant at 0.05 level

Note: all other variables are not significant

One research looked at principal leadership practices, teachers' effectiveness, and academic achievement are found to have a significant correlation. After conducting research, it was found that shared leadership had a greater effect on teachers' commitment. On the other hand, shared leadership may have contributed to the difference in academic communities, particularly the teachers (Sun \& Xia, 2018). Administrators must establish a school's vision, monitor the quality of teaching, and supervise teachers' professional development to be effective in instructional leadership. The heroism of teachers 
may have a modest influence on their perceptions of efficacy, trust, and academic attention as a result of teaching and transformational leadership. However, a school environment with shared leadership may boost teachers' academic confidence. They trust teachers, interact openly with them, provide them the chance to be school leaders, give them the power and duty to make critical choices. They could develop a stronger sense of belonging and commitment to their work, collaborate on school improvement issues and build more trust and respect among themselves and students if they had access to strong distributed leadership (Bellibas \& Liu, 2018).

\section{Conclusion}

This study shed light on the interplay of principal shared leadership, teachers' soft skills development, and learners' competitiveness. It employed a descriptive correlational research design. The survey was done using online. From the study, it can be inferred that the highly positive results are seen on the level of principal shared leadership practices are manifested by the school heads, teachers' soft skills enhancement, and learners' competitiveness. The school heads are capable of exuding shared leadership aspects on effective communication, proper coordination, direction, and influence. Test of relationship showed that there is a positive interplay between principal's shared leadership with the selected variables on teachers' soft skills and learners' competitiveness. The result of this present study will provide a way for policymakers and other stakeholders to develop a plan of action to strengthen principal leadership in the COVID 19 era. Research on the comparative impacts of leadership styles will assist policymakers and practitioners in better understanding that leadership techniques are most successful for specific elements of school reform efforts, in our view.

\section{Recommendations and Implications to Economics of Education}

According to findings from this research, school leaders should examine their leadership methods to better support teachers' soft skills to perform effectively and help students become more competitive. As an implication to the economics of education, this paper may be used by education authorities to allocated funding and develop programs to improve the leadership skills of principals, particularly those in rural or distant locations. Government agencies may also allocate funds for the education sector, focusing on the competencies of school principals in this COVID 19 era. Further, principals need to improve their leadership practices based on the evaluation results to better advise their teachers to accomplish effective school programs and activities. Teachers may maintain their soft skills by often exercising throughout their everyday interactions in the classroom. In order to boost the morale of students, principals are encouraged to assist them in their preparation for any competition by providing them with sufficient resources. Learners are reminded to have a positive attitude throughout. The research suggests that additional factors be investigated to improve the effectiveness of primary school instructors. Regarding self-realization for instructors in terms of job commitment and devotion, may they utilize this research as trustworthy information on the reward of being performance- and service-oriented? The study suggests more research among public elementary schools using new ideas on motivating school administrators' skills, teachers' work environment, and their gross salaries to future researchers. We suggest looking at other aspects that may help instructors perform better. More research with larger sample size is needed to examine the connection between teachers' performance and their principals' motivating abilities, work environment, gross salaries, and other variables that were not included in the study. There were only a restricted number of volunteers. Thus, the study could be kept under control, allowing for a more comprehensive outcome as a consequence. We couldn't access our target audience, but we got enough overall responses to meet the criteria. It is hoped that this limitation would serve as a springboard for further study in the future.

\subsection{Theoretical Implications}

Results of the research corroborate Bandura's Social Cognitive Theory, which emphasizes the individual's cognition concerning his environment. According to the article, students' ability to 
compete depends on their ability to do the activities and their will to attain whatever objectives they want, given the encouragement and support of instructors. According to McClelland's Theory of Needs, people's achievement needs are affected by their behavior. Principals' roles and responsibilities are becoming increasingly complicated as schools confront growing accountability demands. A fresh viewpoint on leadership emerges as a result of this. The term shared leadership is unclear and changes from one source to another. Scholars don't have a single word to refer to it by. Determining the dispersed viewpoint of shared leadership is for improved educational results. Every employee must work together and assume a leadership role (Liu, Bellibaş, \& Gümüş, 2021). According to another line of study, shared leadership is the participation of various individuals in the school's decision-making processes (Abrams et al., 2020). Involvement encourages everyone involved in the school's educational procedures and outcomes to take greater responsibility, particularly this onslaught of the COVID 19 Pandemic.

\section{References}

1. Abrams, E. M., Shaker, M., Oppenheimer, J., Davis, R. S., Bukstein, D. A., \& Greenhawt, M. (2020). The challenges and opportunities for shared decision making highlighted by COVID-19. The Journal of Allergy and Clinical Immunology: In Practice.

2. Ahlström, B., Leo, U., Norqvist, L., \& Isling, P. P. (2020). School leadership as (un) usual. Insights from principals in Sweden during a pandemic. International Studies in Educational Administration (Commonwealth Council for Educational Administration \& Management (CCEAM)), 48(2), 35-41.

3. Al Saidi, A. M. O., Nur, F. A., Al-Mandhari, A. S., El Rabbat, M., Hafeez, A., \& Abubakar, A. (2020). Decisive leadership is a necessity in the COVID-19 response. Lancet (London, England), 396(10247), 295.

4. Allal-Chérif, O., Guijarro-García, M., Ballester-Miquel, J. C., \& Carrilero-Castillo, A. (2021). Being an ethical leader during the apocalypse: Lessons from the walking dead to face the COVID-19 crisis. Journal of Business Research, 133, 354-364.

5. Al-Mekhlafi, A. M., \& Osman, M. E. T. (2019). The effect of a holistic school improvement model in enhancing school effectiveness in Oman. Malaysian Journal of Learning and Instruction, 16(2), 187200.

6. Arcinas, M. M., Sajja, G. S., Asif, S., Gour, S., Okoronkwo, E., \& Naved, M. ROLE OF DATA MINING IN EDUCATION FOR IMPROVING STUDENTS PERFORMANCE FOR SOCIAL CHANGE. Turkish Journal of Physiotherapy and Rehabilitation, 32, 3.

7. Ardley, J., \& Goodloe, A. (2020, June). Working with Principal Interns during the 2020 Pandemic of COVID 19: Moving From Frustrations to Resolutions. In EdMedia+ Innovate Learning (pp. 1-11). Association for the Advancement of Computing in Education (AACE).

8. Bacher-Hicks, A., Goodman, J., \& Mulhern, C. (2021). Inequality in household adaptation to schooling shocks: Covid-induced online learning engagement in real time. Journal of Public Economics, 193, 104345.

9. Bhute, V. J., Inguva, P., Shah, U., \& Brechtelsbauer, C. (2021). Transforming Traditional Teaching Laboratories for Effective Remote Delivery-A Review. Education for Chemical Engineers.

10.Bloomfield, J., \& Fisher, M. J. (2019). Quantitative research design. Journal of the Australasian Rehabilitation Nurses Association, 22(2), 27-30.

11.Boin, A., Lodge, M., \& Luesink, M. (2020). Learning from the COVID-19 crisis: an initial analysis of national responses. Policy Design and Practice, 3(3), 189-204.

12.Chaaban, Y., Arar, K., Sawalhi, R., Alhouti, I., \& Zohri, A. (2021). Exploring teachers' professional agency within shifting educational contexts: A comparative study of Lebanon, Qatar, Kuwait, and Morocco. Teaching and Teacher Education, 106, 103451.

13.Chiodini, J. (2020). Online learning in the time of COVID-19. Travel medicine and infectious disease, 34, 101669. 
14.Debbarma, I., \& Durai, T. (2021). Educational disruption: Impact of COVID-19 on students from the Northeast states of India. Children and youth services review, 120, 105769.

15.Díez, F., Villa, A., Lopez, A. L., \& Iraurgi, I. (2020). Impact of quality management systems in the performance of educational centers: educational policies and management processes. Heliyon, 6(4), e03824.

16.Dong, C., Cao, S., \& Li, H. (2020). Young children's online learning during COVID-19 pandemic: Chinese parents' beliefs and attitudes. Children and youth services review, 118, 105440.

17.Elfrianto, E., Dahnial, I., \& Tanjung, B. N. (2020). The competency analysis of principal against teachers in conducting distance learning in Covid-19 pandemic. Jurnal Tarbiyah, 27(1).

18.Erol, O., \& Kurt, A. A. (2017). The effects of teaching programming with scratch on pre-service information technology teachers' motivation and achievement. Computers in Human Behavior, 77, 11-18.

19.Fernandez, C. F., \& Vecchio, R. P. (1997). Situational leadership theory revisited: A test of an acrossjobs perspective. The Leadership Quarterly, 8(1), 67-84

20.Frey, T. K., \& Tatum, N. T. (2016). Hoverboards and "hovermoms": helicopter parents and their influence on millennial students' rapport with instructors. Communication Education, 65(3), 359361.

21.Gonzales, M. M., \& Jackson, I. (2020). Going the Distance: What School Administrators Can Learn from One-to-One Laptop Schools. Journal of School Administration Research and Development, 5 , 55-60.

22.Goodson, J. R., McGee, G. W., \& Cashman, J. F. (1989). Situational leadership theory: A test of leadership prescriptions. Group \& Organization Studies, 14(4), 446-461.

23.Grosemans, I., Boon, A., Verclairen, C., Dochy, F., \& Kyndt, E. (2015). Informal learning of primary school teachers: Considering the role of teaching experience and school culture. Teaching and Teacher Education, 47, 151-161.

24.Grum, D. K., \& Grum, B. (2015). Competitiveness and motivation for education among university students. IJONTE.

25.Gyang, T. S. (2020). Educational Leadership Response to the COVID-19 Pandemic Crisis in Nigeria. International Studies in Educational Administration (Commonwealth Council for Educational Administration \& Management (CCEAM)), 48(3), 73-79.

26. Harris, A. (2020). COVID-19-school leadership in crisis?. Journal of Professional Capital and Community.

27.Hulpia, H., \& Devos, G. (2010). How distributed leadership can make a difference in teachers' organizational commitment? A qualitative study. Teaching and teacher education, 26(3), 565-575.

28.Hussein, E., Daoud, S., Alrabaiah, H., \& Badawi, R. (2020). Exploring undergraduate students' attitudes towards emergency online learning during COVID-19: A case from the UAE. Children and youth services review, 119, 105699.

29. Hutagalung, L., Purwanto, A., \& Prasetya, A. B. (2020). The Five Leadership Style in Time of Pandemic Covid-19 throughout Industrial Revolution 4.0 as compared to Humane Leadership. International Journal of Social, Policy and Law, 1(1), 79-87.

30.Ignacio, L. B. R., Arcinas, M. M., Eusebio, M. C., Cruz, J. M. D., Dagalea, A. B., Aifianus, M., ... \& Doron, R. O. (2020). Correlates of Perception of COVID-19 health risk among Filipino youth in a private university in Manila, Philippines. Asia Pacific Journal of Multidisciplinary Research, 8(4).

31.Kar, T., Özdemir, E., İpek, A. S., \& Albayrak, M. (2010). The relation between the problem posing and problem solving skills of prospective elementary mathematics teachers. Procedia-Social and Behavioral Sciences, 2(2), 1577-1583.

32.Lai, T. T., Luen, W. K., Chai, L. T., \& Ling, L. W. (2014). School principal leadership styles and teacher organizational commitment among performing schools. Journal of global business management, 10(2), 67. 
33.Lee, J. C. K., Zhang, Z., \& Yin, H. (2011). A multilevel analysis of the impact of a professional learning community, faculty trust in colleagues and collective efficacy on teacher commitment to students. Teaching and teacher education, 27(5), 820-830.

34.Liu, Y., Bellibaş, M. Ş., \& Gümüş, S. (2021). The effect of instructional leadership and distributed leadership on teacher self-efficacy and job satisfaction: Mediating roles of supportive school culture and teacher collaboration. Educational Management Administration \& Leadership, 49(3), 430-453.

35.Lopez, K. R. B., Gaticales, N. P., Provido, A. V. C., Santelices, S. M. B., \& Arcinas, M. M. (2021). Social Contagion of Astrology in the Social Media amid COVID-19 Pandemic. International Journal of Multidisciplinary: Applied Business and Education Research, 2(4), 349-363.

36.Love, P. E., Ika, L., Matthews, J., \& Fang, W. (2020). Shared leadership, value and risks in large scale transport projects: Re-calibrating procurement policy for post COVID-19. Research in Transportation Economics, 100999.

37.Magulod Jr, G. C. (2017). Factors of school effectiveness and performance of selected public and private elementary schools: implications on educational planning in the Philippines. Asia Pacific Journal of Multidisciplinary Research, 5(1), 73-83.

38.Mukaram, A. T., Rathore, K., Khan, M. A., Danish, R. Q., \& Zubair, S. S. (2021). Can adaptiveacademic leadership duo make universities ready for change? Evidence from higher education institutions in Pakistan in the light of COVID-19. Management Research Review.

39.Navaridas-Nalda, F., Clavel-San Emeterio, M., Fernández-Ortiz, R., \& Arias-Oliva, M. (2020). The strategic influence of school principal leadership in the digital transformation of schools. Computers in Human Behavior, 112, 106481.

40.Netolicky, D. M. (2020). School leadership during a pandemic: navigating tensions. Journal of Professional Capital and Community.

41.Ngang, T. K., Yie, C. S., \& Shahid, S. A. M. (2015). Quality teaching: Relationship to soft skills acquisition. Procedia-Social and Behavioral Sciences, 191, 1934-1937.

42.Nuncio, R. V., Arcinas, M. M., Lucas, R. I. G., Alontaga, J. V. Q., Neri, S. G. T., \& Carpena, J. M. (2020). An E-learning outreach program for public schools: Findings and lessons learned based on a pilot program in Makati City and Cabuyao City, Laguna, Philippines. Evaluation and Program Planning, $82,101846$.

43.Özkan, M., \& ÇAKIR, Ç. (2017). Development of distributed leadership scale. Int. J. Eurasia Soc. Sci, 8, 1629-1660.

44.Price, D. C., \& Mansfield, K. C. (2021, February). Leadership in the Time of COVID: Connecting Community Resources to Meet the Needs of North Carolina Students. In Frontiers in Education (Vol. 5, p. 313). Frontiers.

45.Qizi, E. D. A. (2019). Improvement of problem solving skills of english teachers through case study. Наука и образование сегодня, (12 (47)).

46. Rebele, J. E., \& Pierre, E. K. S. (2019). A commentary on learning objectives for accounting education programs: The importance of soft skills and technical knowledge. Journal of Accounting Education, 48, 71-79.

47.Reyes-Guerra, D., Maslin-Ostrowski, P., Barakat, M. Y., \& Stefanovic, M. A. (2021, March). Confronting a Compound Crisis: The School Principal's Role During Initial Phase of the COVID-19 Pandemic. In Frontiers in Education (Vol. 6, p. 87). Frontiers.

48.Saleem, A., Aslam, S., Yin, H. B., \& Rao, C. (2020). Principal leadership styles and teacher job performance: Viewpoint of middle management. Sustainability, 12(8), 3390.

49.Sanger, M. N., \& Osguthorpe, R. D. (2011). Teacher education, preservice teacher beliefs, and the moral work of teaching. Teaching and teacher education, 27(3), 569-578.

50.Sapian, N. R. B., Abdullah, R. B. B., Ghani, M. F., Abdullah, Z., \& Omar, I. M. B. (2020, February). The Relationship Between Principal" s Communication Style and School Climate. In 3rd International Conference on Research of Educational Administration and Management (ICREAM 2019) (pp. 197205). Atlantis Press. 
51.Schott, C., van Roekel, H., \& Tummers, L. (2020). Teacher leadership: A systematic review, methodological quality assessment and conceptual framework. Educational Research Review, 100352.

52.Scott-Young, C. M., Georgy, M., \& Grisinger, A. (2019). Shared leadership in project teams: An integrative multi-level conceptual model and research agenda. International Journal of Project Management, 37(4), 565-581.

53.Selamat, N., Nordin, N., \& Adnan, A. A. (2013). Rekindle teacher's organizational commitment: the effect of transformational leadership behavior. Procedia-Social and Behavioral Sciences, 90, 566574.

54.Shen, J., Ma, X., Mansberger, N., Wu, H., Palmer, L. A. B., Poppink, S., \& Reeves, P. L. (2021). The relationship between growth in principal leadership and growth in school performance: The teacher perspective. Studies in Educational Evaluation, 70, 101023.

55.Shen, J., Wu, H., Reeves, P., Zheng, Y., Ryan, L., \& Anderson, D. (2020). The association between teacher leadership and student achievement: A meta-analysis. Educational Research Review, 100357.

56.Shimotsu-Dariol, S., Mansson, D. H., \& Myers, S. A. (2012). Students' academic competitiveness and their involvement in the learning process. Communication Research Reports, 29(4), 310-319.

57.Smith, T. E., Reinke, W. M., Herman, K. C., \& Sebastian, J. (2021). Exploring the link between principal leadership and family engagement across elementary and middle school. Journal of School Psychology, 84, 49-62.

58.Star, J. R., Newton, K., Pollack, C., Kokka, K., Rittle-Johnson, B., \& Durkin, K. (2015). Student, teacher, and instructional characteristics related to students' gains in flexibility. Contemporary Educational Psychology, 41, 198-208.

59.Sterrett, W., \& Richardson, J. W. (2020). Supporting professional development through digital principal leadership. Journal of Organizational \& Educational Leadership, 5(2), 4.

60.Sumarjoa, B., \& Muhammadc, M. I. (2021). The Principal in Forming Teacher Work Motivation in the Covid-19 Pandemic Period at Senior High School 1 Sigli. teaching and learning, 15(5).

61.Sun, A., \& Xia, J. (2018). Teacher-perceived distributed leadership, teacher self-efficacy and job satisfaction: A multilevel SEM approach using the 2013 TALIS data. International Journal of Educational Resea Bellibas \& Liu, 2018rch, 92, 86-97.

62.Swaminathan, N., Govindharaj, P., Jagadeesh, N. S., \& Ravichandran, L. (2021). Evaluating the effectiveness of an online faculty development programme for nurse educators about remote teaching during COVID-19. Journal of Taibah University Medical Sciences, 16(2), 268-273.

63.Vecchio, R. P. (1987). Situational Leadership Theory: An examination of a prescriptive theory. Journal of applied psychology, 72(3), 444.

64.Vu, C. T., Hoang, A. D., Than, V. Q., Nguyen, M. T., Dinh, V. H., Le, Q. A. T., ... \& Nguyen, Y. C. (2020). Dataset of Vietnamese teachers' perspectives and perceived support during the COVID-19 pandemic. Data in brief, 31, 105788.

65.Wanner, T., \& Palmer, E. (2015). Personalising learning: Exploring student and teacher perceptions about flexible learning and assessment in a flipped university course. Computers \& Education, 88, 354-369.

66.Whitaker, M. C., \& Valtierra, K. M. (2018). Enhancing preservice teachers' motivation to teach diverse learners. Teaching and Teacher Education, 73, 171-182.

67.Yao, J., You, Y., \& Zhu, J. (2020). Principal-teacher management communication and teachers' job performance: the mediating role of psychological empowerment and affective commitment. The Asia-Pacific Education Researcher, 29(4), 365-375.

68.Yavuz, G., Arslan, C., \& Gulten, D. C. (2010). The perceived problem solving skills of primary mathematics and primary social sciences prospective teachers. Procedia-Social and Behavioral Sciences, 2(2), 1630-1635.

69.Zadeh, E. F., Parry, Y., \& Eshghi, P. (2021). Hope in Iranian mothers of children with cancer: a descriptive correlational study. Supportive Care in Cancer, 29(7), 3697-3705. 
Interplay of Shared Leadership Practices of Principals, Teachers' Soft Skills and Learners' Competitiveness in COVID 19 Era: Implications to Economics of Educational Leadership

70.Zhou, C. (2021). The effectiveness of 5E model to improve the scientific creativity of teachers in rural areas. Thinking Skills and Creativity, 41, 100900.

71.Ziauddeen, N., Woods-Townsend, K., Saxena, S., Gilbert, R., \& Alwan, N. A. (2020). Schools and COVID-19: Reopening Pandora's box?. Public Health in Practice, 1, 100039. 